\title{
ANALYSIS OF IMPLEMENTING SPATIAL AND TRAFFIC STUDIES IN THE DEVELOPMENT OF PHYSICAL PLANNING DOCUMENTS OF PRIMORJE-GORSKI KOTAR COUNTY
}

\begin{abstract}
The new generation of physical planning documents requires adaptation to new economic and other development plans as well as to new parameters of the modern society development. Therefore, it is necessary to insure high-quality planning foundations which will serve as the basis to determine the basic guidelines of physical plans. This refers especially to the need for integral consideration of the development of traffic and the traffic infrastructure in compliance with the space requirements and possibilities. In order to evaluate the objective parameters of physical and traffic planning, the traffic studies carried out as required for the production of the physical planning documentation of the new generation have been analyzed. The goal of research was to determine the credibility of infrastructure development plans predefined by the documents of physical planning from the region of the Primorje-Gorski Kotar County. The paper presents the results of initial research carried out for the requirements of producing the Physical and Traffic Integral Study of the Primorje-Gorski Kotar County and the city of Rijeka. According to overall distribution of responses it may be concluded that there is great gap in knowing the procedures of traffic and spatial planning among specialized traffic agencies and the rest of the respondents.
\end{abstract}

\section{KEY WORDS}

physical and traffic planning, urbanism, physical planning documentation, space-traffic interrelation

\section{INTRODUCTION}

Upon gaining independence the Republic of Croatia saw significant changes in her physical and urban planning. New urbanistic standards and values were adopted, which had to be articulated also through the physical and planning documentation. Therefore, the second half of 1990s saw intensive activities in producing the strategic physical planning documentation at the government and county levels, only to start at the beginning of the decade with active development of strategic and implemental physical planning docu- mentation at the local level. The new generation of physical planning documents requires adaptation to new economic and other development plans as well as to new development parameters of the modern society. Therefore, it is necessary to insure high-quality planning foundations which will serve as the basis for determining the basic guidelines of the physical plans. This refers particularly to the need for integral consideration of the development of traffic and traffic infrastructure in compliance with the space requirements and possibilities.

In attempting to realize operatively the objectives determined by physical planning documents in the Primorje-Gorski Kotar County, the lack of unity in the development plans of different traffic infrastructures has been observed, i.e. inconsistency of sector development plans in relation to global traffic conditions. In order to evaluate the objective parameters of physical and traffic planning, the traffic studies carried out in the past for the needs of producing the physical planning documentation of new generation ${ }^{1}$ have been analyzed. The objective of the studies was to determine the credibility of the infrastructure development plans predefined by the physical planning documents from the region of the Primorje-Gorski Kotar County. The paper presents the results of initial research carried out for the needs of producing the Physical and Traffic Integral Study of the Primorje-Gorski Kotar County and the City of Rijeka. The references to the earlier physical-traffic and traffic studies and researches have been provided only for the sake of comparison with the found condition of the currently actual physical planning documentation, whereas the results of the carried out survey have been elaborated in detail. A number of bibliographic units of national and foreign authors have been consulted and these show the activities as part of the study of the interrelation of the space facilities and the traffic flows, but not the analysis of the trend of using and implementing these, elementary studies in the physical planning documents. 
In order to meet efficiently the research objectives the following scientific methods have been used: the survey method based on quality indicators, face-toface consultations, as well as telephone surveys, i.e. e-mail surveys.

\section{PHYSICAL AND TRAFFIC INTEGRAL STUDY OF PRIMORJE-GORSKI KOTAR COUNTY AND THE CITY OF RIJEKA}

The Primorje-Gorski Kotar County is located in the northernmost part of the Adriatic and the Mediterranean. The value of the geographic position of the Primorje-Gorski Kotar County lies precisely in the fact that it is located on the crossroads of the Central European and Adriatic-Mediterranean routes, on the specific area that represents the interface of two significantly different geographic regions, Gorski Kotar and Primorje (Littoral) with the islands. The population of the County amounts to 305,505 with almost half of this number living in the area of the City of Rijeka, more precisely 144,043 citizens $^{2}$. The Primorje-Gorski Kotar County covers a total area of $7,986.64 \mathrm{~km}^{2}$, out of which $4,398.64 \mathrm{~km}^{2}$ (55.075\% of the total area of the Primorje-Gorski Kotar County) cover the sea. The total length of the sea coast is $1,065 \mathrm{~km}$.

The physical plan of the Primorje-Gorski Kotar County has defined, among other things, the primary traffic network of corridors, i.e. routes and nodes, and it has been classified into those of state and those of the county significance. The backbone of such existing network consists of the maritime and land infrastructure, mainly ports, road and rail infrastructure and infrastructure of air and pipeline traffic as well as telecommunications.

The topographic characteristics and the lack of space in the centre of the County do not allow hierarchical development of the traffic network. The coexistence and the development of the two complex systems such as the City of Rijeka (centre and capital of the Primorje-Gorski Kotar County) and the Port of Rijeka (state port of special international interest for the Republic of Croatia and the land-locked countries in its hinterland) greatly depend on the "Traffic junction Rijeka". The traffic junction model is in fact the only possible solution in this highly valuable, but also confined littoral space. Therefore, the traffic junction is the key traffic component given by the Physical Plan of the Primorje-Gorski Kotar County, inaugurated as a physical traffic model of unique category in the County centre. It represents the intersection of two traffic routes (North-South and West-Southeast) and it should be realised integrally in all the segments of the traffic functions, simultaneously with the traffic routes. Here, the primary traffic routes, i.e. corridors, in the region of the Primorje-Gorski Kotar County of state to international significance, mean the Pan-European Corridor Vb (transversal), and the Adriatic-Ionian (Iongitudinal) corridor. These traffic corridors along with the "Traffic junction Rijeka" represent the backbone of the County traffic system. The very "Traffic junction Rijeka” primarily encompasses the port-terminal, rail and road junctions, which does not exclude other traffic branches [1].

The traffic supply in the centre of the PrimorjeGorski Kotar County, due to the strong component on both traffic routes, is disintegrated and therefore, very expensive. The heritage of the traffic network of the Primorje- Gorski Kotar County, and especially in the City of Rijeka cannot further satisfy in a good manner the traffic demands of the development of the Port of Rijeka and the City in the centre of the County. Under such influence of international traffic (transit of goods as well as passengers) the organisation of other traffic components related to the development of the City of Rijeka is rendered difficult, also affecting the integration of coastal, land and especially island units of local self-government. This fact is additionally aggravated by establishing of eight toll booths on state traffic routes without adequate alternatives, which is in this region additionally complicated by the terrain configuration as well as the complexity of urban structures. All this leads to the conclusion that the only possible solution lies in the construction of an integral multimodal traffic system whose traffic and spatial role will give incentive and insure further development of the region, including also the increase in the quality of living of the local population, in accordance to the tolerance of the space and tailored to humans [2].

Recognizing the necessity of comprehensive consideration of the development of traffic infrastructure in the Primorje-Gorski Kotar County (PGŽ), and especially the wider agglomeration region of the City of Rijeka, the development of the Physical and Traffic Integral Study of the Primorje-Gorski Kotar County and the City of Rijeka started in 2008. The specific characteristic is that for the first time in monitoring the development of the physical-traffic study there is participation of all the subjects responsible for individual segments within the traffic system ${ }^{3}$.

The role of the Study is to articulate the development plans per all traffic branches and to unify them integrally and dimension them into a single unique traffic system. It has to offer adequate integral solutions of routes, capacities and phase-like construction of individual traffic infrastructure up to the year 2040 inclusive.

As part of the study it was necessary to determine and to revise the previous development plans, as well as to determine the credibility of the infrastructure development plans pre-defined by the spatial planning documents. The Study will present the results of the carried out analyses of the found traffic network condi- 


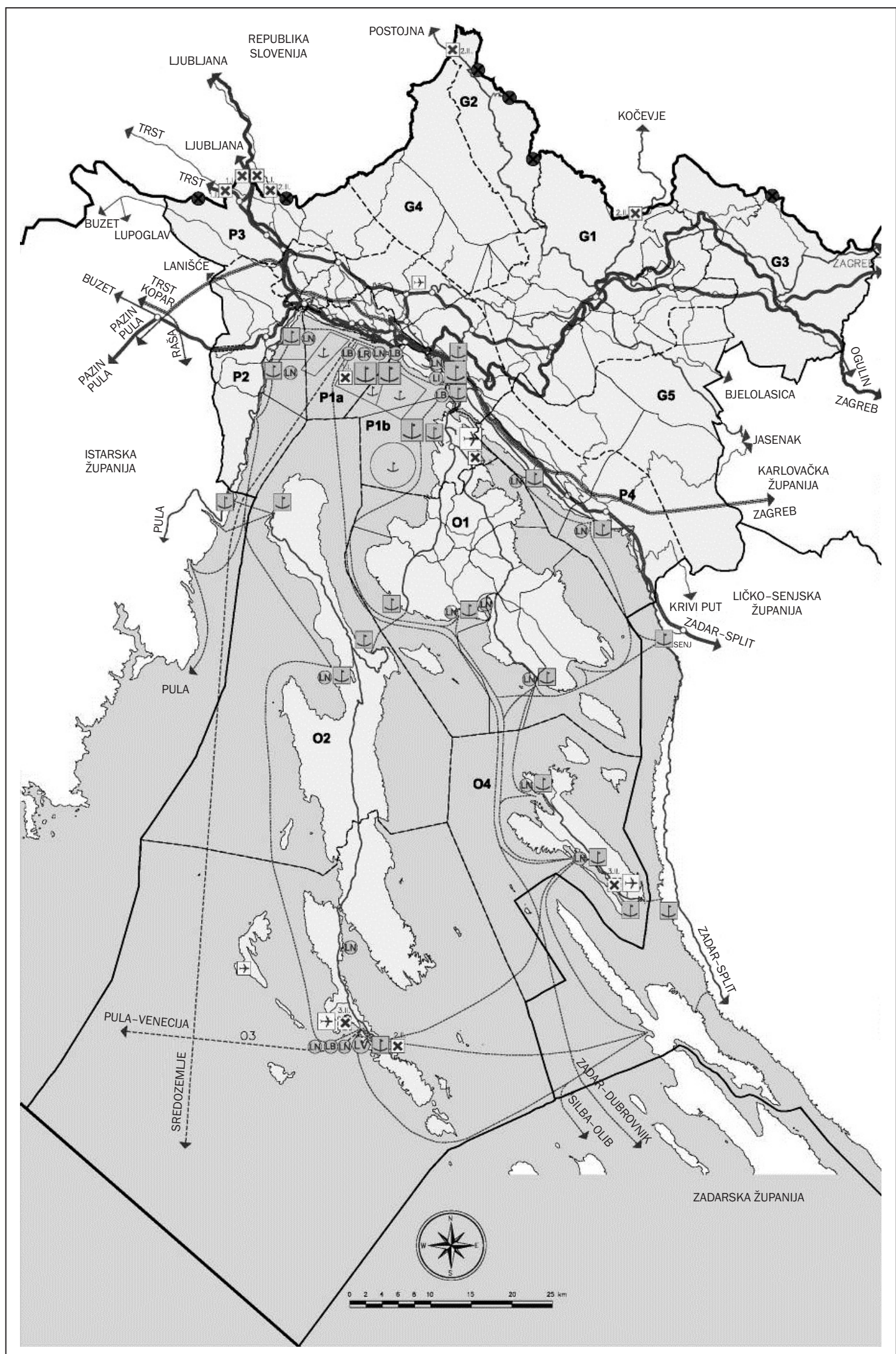

Schema 1 - Traffic system of the Primorje-Gorski Kotar County

Source: Physical plan of the Primorje-Gorski Kotar County, "Official newspapers of the Primorje-Gorski Kotar County", 2000, 14, 2005, 10, 2006, 50, 2009, 08, adapted by the author 
tion, the existing traffic load and the expected traffic forecasts, and it will propose the concept and the traffic solutions of re-defining the road, rail, sea, air and pipeline traffic in the Primorje-Gorski Kotar County. The Study should eventually represent a professional background in the segment of traffic and traffic infrastructure for the needs of additional elaboration, improvement and amendment of the Physical Plan of the Primorje-Gorski Kotar County [3, 4].

A number of studies of traffic demand, traffic flow, traffic interests of the wider population, etc. have been carried out as part of the Study. However, to determine the starting foundations an initial study of the state in physical and traffic planning in the area of local and regional community was carried out as well as the study of institutions that are authorised to produce the strategic physical planning documentation at the state level.

\section{CHARACTERISTIC, PURPOSE AND OBJECTIVES OF RESEARCH}

Planning and designing of traffic routes is a very complex task which occurs at different levels, starting from the plan consideration of the development of the region as a whole all the way to the concrete technical solutions of single elements and objects. The traffic studies that are produced as professional foundations for the making of physical planning documentation do not recognize sufficiently the interrelation of the space purposes and the needs for its high-quality traffic integration. This results eventually in poor-quality and in practice unfeasible physical planning solutions. The obligation of the experts is to use the applied methodology and procedures in defining an optimal solution taking into consideration all the levels of consequences in compliance with the significance of the region and the plan subject. This requirement results also in the necessity of implementing the planning research as integral part of the planning process which make it possible to make a sufficiently reliable evaluation of the consequences (e.g. economic, environmental, physical, functional, traffic ones, etc.) [5].

Based on this, the significance of the rational physical planning of individual areas and adequate adaptation of the total traffic network to the requirements of the physical structures depending on their purpose is obvious. Therefore, the research problem has been defined for the research requirements which is: a systemic approach to traffic planning through previous elaboration of traffic strategies and physical-traffic studies as the foundation for making the physical plans (of all levels) is not applied in practice. The physical plans define the traffic solutions which are not sufficiently professionally processed, and in their implementation they represent a significant limitation of the sub- sequent balanced traffic and economic development. Although numerous problems and phenomena related to traffic and traffic planning in the Republic of Croatia have been studied for several decades, the quantum of actual explicit, implicit, disciplinary and multidisciplinary knowledge, theories, laws (...) about the interrelation of space and traffic infrastructure, which the students, intellectuals, engineers, entrepreneurs, managers, politicians (...) acquire, have, own, implement (...) is extremely unsatisfactory, which directly implies numerous negative consequences.

The mentioned research problem has been defined regarding space, time and notion. The physical boundaries of the research problem are determined within the pre-set scope boundaries of the physicalplanning documentation, with special focus on the region of the Primorje-Gorski Kotar County. The time limits of the research problem refer to the period of 8-10 years ago (from 1998 to 2008) i.e. time period in which physical-planning documentation of the new generation started to be developed. The time limit in a wider sense includes also a review of the previous and proposed future research of the mentioned problems. The notional limits of the research problem determine the study of the traffic system evaluation, especially of the Primorje-Gorski Kotar County, regarding the high demands of the space and in compliance with the traditional guidelines (traffic system in compliance with the development values of small Mediterranean centres).

The purpose of research is to use scientific and research methods to determine the previous levels of implementing the physical-traffic studies in developing the physical planning documents.

The objective of research is to use the scientifically founded research methodology as the basis for analysing concrete experiences of all the participants in the procedure of making and adopting the physical planning documents, to determine the sufficiency of the current model of considering the development of the traffic system, i.e. to prove the insufficiency in considering the development of traffic and traffic infrastructure.

In order to rationalise the research area, and with the aim of evaluating the objective parameters of physical-traffic planning in the Primorje-Gorski Kotar County, this work analyses the traffic studies carried out precisely for the needs of producing the physicalplanning documentation of the new generation.

\section{SAMPLE SCOPE AND RESEARCH METHODOLOGY}

In order to collect the objective and reference data the research was done on two occasions, i.e. two groups of questionnaires were used. First, a prelimi- 
nary research was carried out in mid-2008, in which all the units of local self-government from the region of the Primorje-Gorski Kotar County were contacted with the inquiry relating to the existence of the traffic and physical-traffic studies for the needs of developing a strategic physical planning documentation, which would be worth including into the Physical and Traffic Integral Study of the Primorje-Gorski Kotar County and the City of Rijeka. Out of 36 sent inquiries, answers were received from only three local self-government units. From the received answers, but also through subsequent telephone checks of the local self-government units that did not provide their answers, it was obvious that no special traffic or physical-traffic research had been done for the needs of making the physical plans of the districts/city planning. As a rule, the solutions set by the plans of the higher order were accepted, i.e. new solutions were proposed without good and comprehensive integral traffic verification.

The second research was in fact a survey sent by e-mail on 21 October 2009 with response deadline by 10 November 2009. In order to include a representative sample ${ }^{4}$ again all the units of local self-government from the County region were selected as well as all the urban planners from the Republic of Croatia who are licensed to perform the activities of developing physical plans as well as all the civil engineering and traffic/maritime faculties in the Republic of Croatia, and the design agencies with references in traffic planning. The Primorje-Gorski Kotar County consists of a total of 36 local self-government units. The Ministry of Environmental Protection, Physical Planning and Construction has granted at the level of the Republic of Croatia for the development of strategic physical-planning documentation a total of 51 licenses (out of which seven institutions have been registered in the area of the Primorje-Gorski Kotar County). The questionnaire was also forwarded to the Faculties of Civil Engineering in Rijeka and Zagreb, Faculty of Civil Engineering and Architecture in Split, Faculty of Architecture in Zagreb, the Maritime University in Rijeka and the Faculty of Transport and Traffic Sciences in Zagreb, as well as to the Institute of Transport and Communications, IGH Institute, companies Elipsa and Prometmilenijum (representing companies that have exceptional references in traffic planning). In this way, the sample was defined at two levels. One at the level of the Republic of Croatia, relating to the study of the overall urban population in the Republic of Croatia as well as of all the faculties and institutions related to the traffic planning, and the other, local level which includes all the self-government units from the Primorje-Gorski Kotar County. Each respondent was guaranteed anonymity at any moment, which was meant to raise the level of sincerity in forming the answers.

The questionnaire included 18 questions requiring answers related to the needs of producing the physi- cal-traffic solutions as well as the actual condition in developing the physical-planning documentation. The number of questions is directly connected with the method of inquiry. It was taken into consideration, namely, that, since the survey was carried out using e-mail, the questionnaire be condensed and concise, in order to gather as many answers as possible. It was structured in such a way that the introductory part required the basic information about the respondent, their education, experience and the affiliation, followed by a group of situation and selective questions and finally a group of verification - control questions [6].

Out of the total number of sent questionnaires, only about 30\% did not come back, which represented a very small percentage of non-respondents since the average is $35-40 \%$, and may reach even as many as $90 \%$ of non-respondents ${ }^{5}$. The reason may lie also in the fact that all who failed to respond to the questionnaire within the set deadline, were contacted by phone and asked to fill in the questionnaire, or, if possible, to provide answers over the phone [7].

\section{REPORT ON PERFORMED RESEARCH}

The results of the survey were analysed at two levels. The first level is, in fact, an analytical division of the groups of responses based on the respondent. They were classified into decision-makers i.e. representatives of the local self-government, licensed urbanistic institutions, higher education institutions and institutions specialised in traffic planning. The second level represents cumulative processing of all the survey questions.

The general question whether traffic analyses had been carried out at their institutions up to now for the needs of producing physical-planning documentation, received negative responses from $33 \%$ of the respondents, whereas only $25 \%$ had made integral physicaltraffic studies, i.e. $17 \%$ of respondents had done separate traffic studies ${ }^{6}$.

As many as $92 \%$ of the respondents emphasised the importance of interactive planning of physical distribution of urban facilities and traffic network elements. The evaluation of the quality of the level of physical-traffic planning at the local, regional and national level varies, but as a rule never does it exceed grade three (good). The grading range used here is from one to five, one meaning the worst and five the best grade.

A large majority of respondents (92\%) responded that for the needs of producing the physical-planning documentation it is necessary to carry out traffic studies. Out of the total number of respondents, $42 \%$ consider it necessary, 33\% think that it is very important and $17 \%$ that it is important. Only $8 \%$ of the respon- 


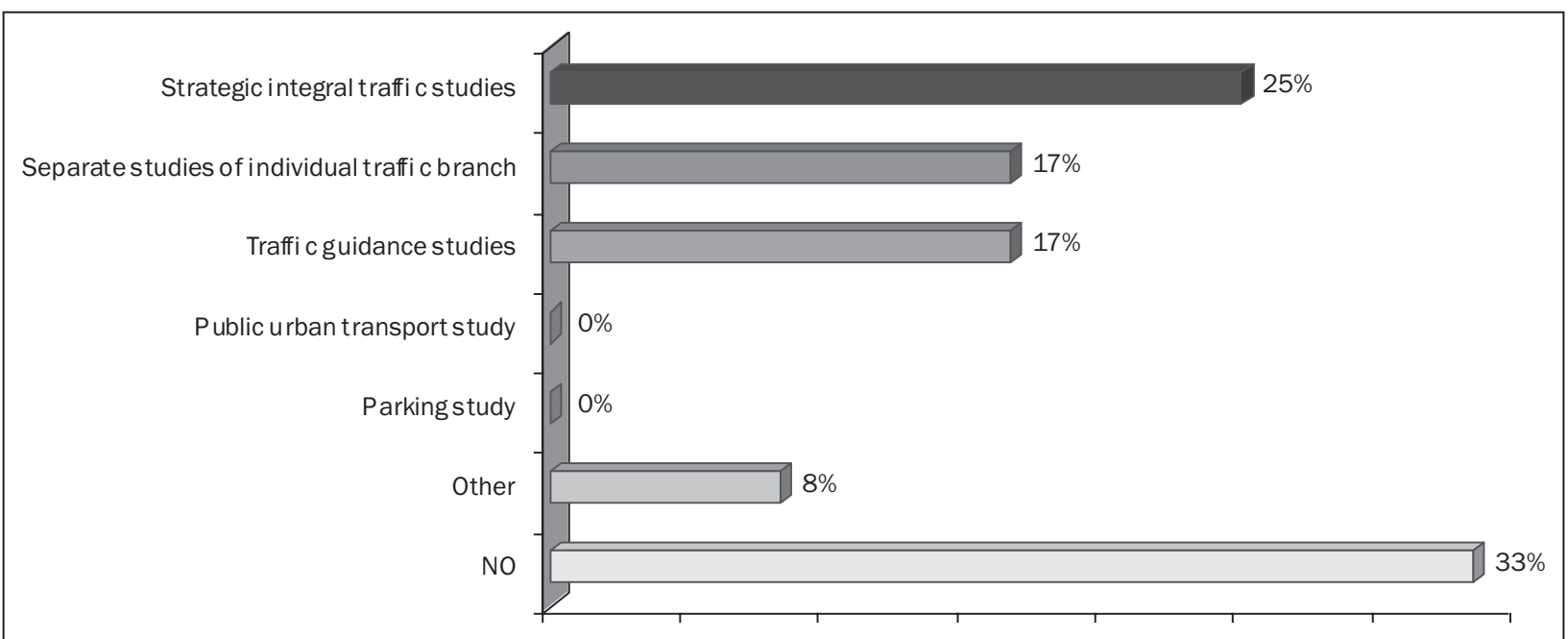

Graph 1 - Answers to survey question 5: Have you carried out traffic analyses at your institution up to now for the needs of developing physical-planning documentation?

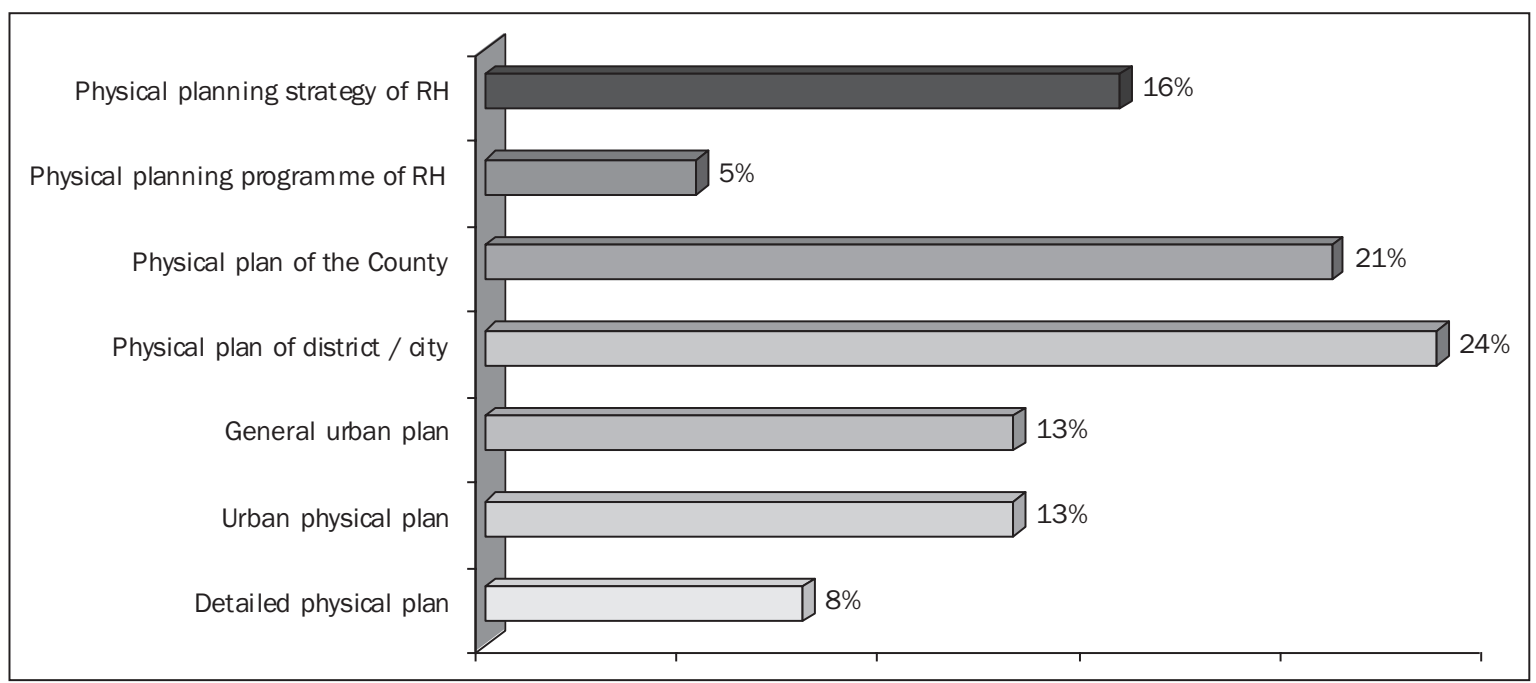

Graph 2 - Answers to survey question 9: At which level of physical-planning documentation, in your opinion, must the strategic physical-traffic analyses be carried out?

dents consider that it is not of major importance, and nobody considers it unimportant i.e. harmful.

Inquired to explicitly indicate the levels of physicalplanning documentation for which strategic physicaltraffic analyses have to be carried out, very symptomatic responses have been received. As a rule, the local self-government units would solve the strategic considerations of the development of traffic infrastructure also in the physical planning implemental documentation, whereas professional and higher education institutions prefer the strategic documentation. The provided responses reflect the elementary lack of knowledge of the essential role of individual levels of the physical planning documentation (especially within the professional services of the local self-government units) and give unnecessary importance to implemental documentation which does not actually have the possibility of good strategic consideration of the traffic system development (only construction solutions / corrections are possible). It is precisely this response which is crucial in confirming the general deficiency and lack of education regarding the required and relevant activities that have to be realised for the needs of making high-quality physical documentation. If the previous two responses are directly correlated with the question about the studies that are carried out for the requirements of physical planning, one may see that the gap and disproportion as well as the lack of understanding of the roles of individual levels of traffic studies are even greater. It is, namely, that 33\% of the respondents had never done traffic studies, only $25 \%$ had done strategic integral traffic studies (which is appropriate) and $17 \%$ had done separate studies of individual traffic branches (which is also useful). The studies of guiding traffic were done by $17 \%$ respondents while the remaining $8 \%$ of respondents carried 
out other traffic studies. It should be noted that, as a rule, the studies of traffic guidance, the studies of public urban transport and parking are used in the realisation / implementation phase of the traffic solutions and in the implementation of the traffic policy and are not necessary for the strategic space considerations. Also, the majority of participants concluded that for the needs of producing the physical planning documents the up-to-now mentioned studies were mainly not carried out (33\%). They blame this on the third persons and institutions, i.e. absence of legal obligations or clear standards and norms, minimizing thus their own role i.e. inactiveness.

To the concrete question about the reasons of the lacking quality of the physical-traffic planning at the level of the Primorje-Gorski Kotar County, the main reasons that were indicated were the absence of political willingness, insufficient knowledge of the professional services and insufficient interconnection with other local self-government units (22\%), insufficient material resources (17\%) and insufficient knowledge of management (13\%). Only $4 \%$ of the respondents answered that the space-traffic planning in the Primorje-Gorski Kotar County is sufficient whereas nobody considers that the cause lies in inadequate legal frame or some other reason. More than $80 \%$ of the respondents emphasised in particular that due to various reasons they avoid comprehensive research for the needs of developing strategic physical planning documents. As a rule, they accept the proposals of the designers, i.e. they adapt final solutions to the current interests of the social and political community not taking into consideration the total implications that these solutions might have.

The distribution of answers related to the opinion of the respondents regarding the importance of interaction of the space facilities and the traffic shows that the great majority thinks that it is extremely important and crucial for the quality of the physical planning documents (42\% of respondents answered that it is very

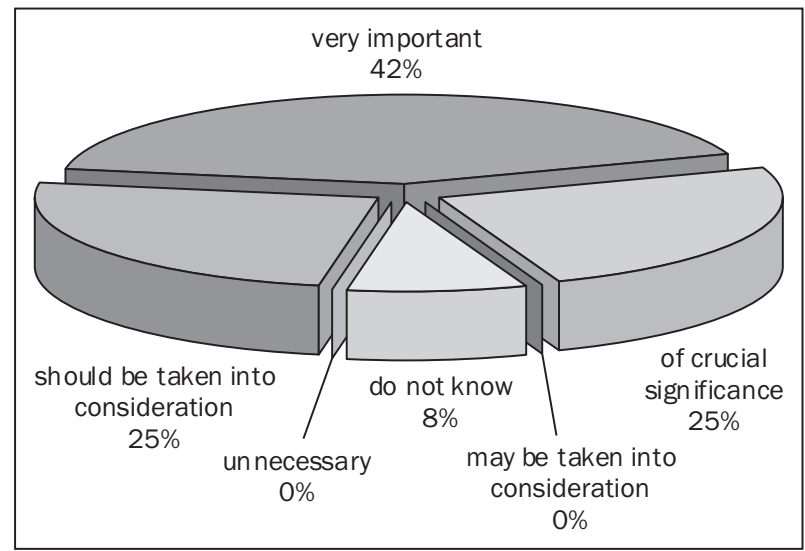

Graph 3 - Answers to survey question 7: How would you grade the importance of interactive planning of physical distribution of urban facilities and traffic network elements? important and another $25 \%$ of respondents that it is of crucial significance).

However, to the concluding question asking the respondents to express their opinion on the need for reurbanisation ${ }^{7}$ that would have to be carried out in a certain area in order to improve the quality of living and work, as many as 33\% of respondents answered that they cannot assess that, 25\% consider it necessary but only exceptionally, $17 \%$ that it is possible with political commitment, $17 \%$ that it is the only solution, and $8 \%$ that it is probable. From the structure of the answers to this question it is easy to conclude that such measures, however necessary, are neither considered nor taken seriously. This is also the reason for the impossibility of finding adequate solution to the traffic problem of big urban environments that could become much more accessible and more humane with the change in structure and in distribution of activities and facilities in the urban centres.

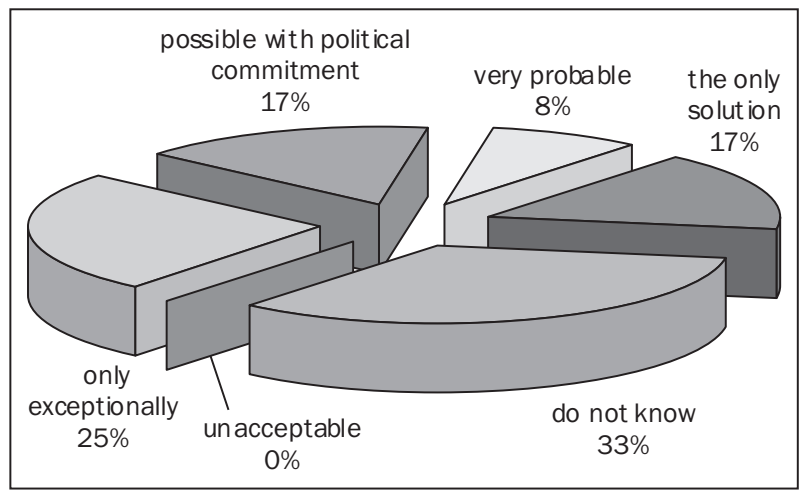

Graph 4 - Answers to survey question 18: Do you think that the start on the proposal to re-urbanise a certain area in order to improve the quality of living and work is objective?

\section{CONCLUSION}

The majority of respondents agreed with the theses that before producing, particularly strategic, physical planning documentation, it is necessary to perform high-quality physical and traffic researches and studies. Similarly, the majority of respondents concluded that for the needs of producing physical planning documents the mentioned researches had mainly never been done, and they blame it on the third persons and institutions i.e. absence of legislative obligations or clear standards and norms, minimizing at the same time their own role i.e. lack of activity. More than $80 \%$ of respondents put special emphasis on the fact that due to various reasons they avoid comprehensive studies for the needs of producing strategic physical planning documents and that as a rule they accept the proposals of designers, i.e. they adapt final solutions to current interests of the social and political community, not taking into account here the overall implications that may result from these solutions. 
Regarding the total distribution of answers it may be concluded that there is a large gap in knowing the procedures of physical and traffic planning between specialised traffic agencies and the rest of the respondents. While traffic experts as a rule understand the significance and role of traffic planning and the multicriteria analyses (with the knowledge of very modern software tools) the rest get in contact with these only in principle. This shows that without clear legal and sub-legal acts it is not possible to define in unison the level of elaboration which has to be processed in single documents of physical planning, related to the planning of traffic infrastructure. It is also obvious that there is need to introduce additional workshops/trainings for professional services of the local communities.

The development of integral physical and traffic studies is a multidisciplinary process, taking into consideration and elaborating all the economic and physical benefits as well as environmental and other consequences resulting from the construction of new traffic infrastructure. Special attention is paid to recognising the protected, agricultural and construction regions. The study of this category is extremely complex, especially regarding collection of information about the number of alternatives (versions) of the studied system. In the context of constant social and physical planning this level of traffic study is a subject of continuous additional processing. In this sense, in all the future time intervals, based on better foundations and more modern interpretations, the study may improve the planned long-term traffic projections and solutions.

The initial research has indicated the seriousness of the problem, and has shown that the experiences related to traffic and space integral studies are reflected in life and solved in practice, which makes it possible and necessary to start the scientific discussion which will be the basis for further scientific and professional training in the segment of traffic planning and possible basis to bring adequate legal and sublegal acts which will stipulate their mandatory development. It is precisely the fact that the problem of systemic traffic planning has not been either in theoretical or practical sense continuously tackled, has resulted in the problem of realizing a good traffic network. This has proven the need to carry out traffic and spatial studies that will represent expert bases for the development of the physical planning strategic documents.

\section{Dr.sc. LUUDEVIT KRPAN}

E-mail: ljudevit.krpan@pgz.hr

Javna ustanova „Zavod za prostorno uređenje

Primorsko-goranske županije“

Splitska 2/II, 51000 Rijeka, Hrvatska

\section{SAŽETAK}

\section{ANALIZA PRIMJENE PROMETNO- PROSTORNIH STUDIJA U IZRADI DOKUMENATA PROSTORNOG UREĐENJA U PGŽ}

Nova generacija dokumenata prostornog uređenja zahtijeva prilagodbu novim gospodarskim i inim razvojnim planovima ali i novim parametrima razvoja suvremenog društva. Stoga je nužno osigurati kvalitetne planerske osnove temeljem kojih će se determinirati bazne odrednice prostornih planova. Ovo se posebno odnosi na potrebu integralnog promišljanja o razvoju prometa i prometne infrastrukture sukladno prostornim potrebama i mogućnostima. Kako bi se valorizirali objektivni parametri prometno-prostornog planiranja analizirana su prometna istraživana učinjena za potrebe izrade prostorno-planske dokumentacije nove generacije. Cilj istraživanje, bio je, utvrditi vjerodostojnost planova razvoja infrastrukture predefiniranih dokumentima prostornog uređenja sa područja Primorskogoranske županije. U radu su predstavljeni rezultati inicijalnog istraživanja provedenog za potrebe izrade Prostorno $i$ prometne integralne studije Primorsko-goranske županije $i$ Grada Rijeke. Prema ukupnoj distribuciji odgovora može se zaključiti kako postoji veliki raskorak u poznavanju postupaka prometno-prostornog planiranja između specijaliziranih prometnih ureda i ostatka ispitanika.

\section{KLUUČNE RIJEČI}

prometno-prostorno planiranje, urbanizam, dokumentacija prostornog uređenja, međuodnos prostora i prometa

\section{REFERENCES}

1. The new generation space and planning documentation means physical planning documents determined after the Republic of Croatia gained independence. This refers primarily to the strategic documents such as the Strategy and Program of physical planning of the Republic of Croatia, physical plans of the County, physical plans of the regions of special significance and physical plans of the cities / districts, and implementation documents such as urban and detailed physical plans.

2. According to the census carried out from 1 April to 15 April 2001.

3. The Ministry of the Sea, Transport and Infrastructure, Primorje-Gorski Kotar County, City of Rijeka, Port Authority Rijeka, Croatian Railways - Infrastructure, Croatian Roads, Rijeka-Zagreb and Croatian Roads Motorways.

4. Representative sample is such a sample which for a determined series of variables looks like the basic set from which it has been drawn, to such an extent that certain specific analyses performed on it give results 
that will fall within acceptable limits set for adequate values of the basic set, and only in a small proportion the results of such analyses of samples will fall outside these limits.

5. Meler, M.: Istraživanje tržišta (Market Research), Faculty of Economics in Osijek, Osijek, 2005, p. 91

6. See Graph 1. The responses to survey question 5 Have you carried out traffic analyses at your institution up to now for the needs of developing physical-planning documentation?

7. The term reurbanism understands changes in the disposition of the physical structure of the already formed urban environments.

\section{LITERATURE}

[1] Krpan, Lj., Šuperina, V., Baričević, H.: Integralni prometni čvor Rijeka-model za razvoj grada i luke, Suvremeni promet, Croatian Scientific Society for Transport, Vol. 30, Opatija, 2010, 1-2

[2] Baričević, H., Poletan-Jugović, T., Krpan, Lj., Šuperina, V.: Prostorno-prometna integralna studija Primorsko- goranske županije i grada Rijeka, Conference on Traffic Systems - Automation in Transportation 2008, Korema, Rijeka, 2008

[3] Dadić, I., Kovač, J., Jurić, I.: Prometno-urbanističko planiranje i projektiranje i sigurnost prometa, Suvremeni promet, Croatian Scientific Society for Transport, Vol. 17, Zagreb, 1997, 1-2

[4] Matoš, S., Županović, l.: Kriteriji i metodika integralnog planiranja prometne mreže, Second Croatian Congress on Roads, Croatian Company for Roads "Via-Vita", Cavtat, 1999

[5] Crnjak, M., Pekanović, T.: Metodologija izrade prostorno-prometnih i tehničkih studija za polaganje trase cesta visokog učinka, Third Croatian Congress on Roads, Croatian Company for Roads "Via-Vita", Cavtat, 2003

[6] Roić, I., et al.: Urbani izazovi-Infrastruktura kao razvojni izazov u većim hrvatskim gradovima, Siemens d.d., Zagreb, 2008

[7] Meler, M.: Istraživanje tržišta, Faculty of Economics in Osijek, Osijek, 2005 